\title{
A COMPARATIVE STUDY ON THE PASSIVITY OF THE STUDENTS LEARNING ENGLISH AS A SECOND LANGUAGE AT ALEKSANDRAS STULGINSKIS UNIVERSITY
}

Ingrida AUGUSTAITIENE், Centre of Cultural Communication and Education, Aleksandras Stulginskis University; Universiteto str. 10, Akadaemija, Kaunas distr., Lithuania; ingrida.augustaitiene@ asu.lt (corresponding author)

Ilona KILDIENE், Centre of Cultural Communication and Education, Aleksandras Stulginskis University, Universiteto str. 10, Akadaemija, Kaunas distr., Lithuania; ilona.kildiene@asu.lt

The article focuses on the comparative analysis of the causative factors influencing the students' passivity in 2005 and 2017 as well as on classwork methods stimulating their activity. The analysis was based on the results obtained in 2005 and 2017 . The results showed that the main reasons of the students' passivity in 2005 during their English classes was their habit to be silent acquired in the high school as well as their unwillingness to show emotions (female approach) and laziness (male approach). In 2017 the students were still unwilling to show their emotions (both female and male approach) and laziness (male approach). In 2005 the active students pointed out discussion as the most acceptable method to acquire competence in the English as the second language, whereas the passive students preferred teamwork to any other classroom activity. Both target groups emphasized the importance of good psychological climate during the classes. In 2017 discussion was found to be the most acceptable method to acquire competence and better speaking skills for the both active students and passive students, while the latter indicated that the psychological climate during the classes as exceptionally important helping them to cope with the stress and language barrier. The obtained results also showed that the students in 2017 were more conscious of the importance of being active during the classes.

Keywords: student passivity, second language, active methods, relaxed atmosphere

\section{INTRODUCTION}

Nobody doubts that European Union and global market touched and is increasingly touching our lives at every level including education and language teaching/learning processes. "A European who speaks only one language is living, without realizing it, in a cage; no matter how roomy or attractive, it is nonetheless a cage. European Unity implies precisely the opening up the cages we live in" (Forrest, 2004). In this context, knowing languages meant and still means a greater participation in social, economic, cultural and political life to say the least of the effective contribution to personal development. The Council of Europe has been active in the promotion of modern language learning and teaching. As an intergovernmental organisation its role has been to assist member states in taking effective measures which will enable all present and future citizens to achieve a degree of communicative competence in a number of languages (plurilingualism) on a lifelong basis, in the interests of better personal mobility, information in a multilingual and multicultural Europe. (Vez, 2009).

In 2005, in Lithuania, we were confronted with a sad fact that a majority of students entering higher education with the experience of eight or more years of instruction of the English at the secondary school had a considerable difficulty in coping with the language in its normal communicative use (Augustaitiene, Barzdziukiene). Then, many students were not willing to participate actively in the classroom activities and learn to communicate a foreign language. Moreover, some of the students were totally unmotivated to learn a foreign language. They had a vague idea of their future needs for the foreign language and career prospects. The possible reason of such a low motivation then might have been a poor background knowledge of the English. Did the situation change by the mid 2017? We naturally expected that the challenges of ongoing globalization and increasing demand for professionals speaking one or two foreign languages might have led to radical changes in student motivation and engagement. Yet, the obtained data revealed that even though the background knowledge improved it seems that the students despite the face -to-face interaction with the instructors and their immense efforts to deliver teaching material effectively using active teaching methods and employing new technologies in the classroom still tend to remain passive and unengaged. In 2012 Mohd. Yusof Abdullach et .al claimed that we often hear from the academic world that the students still do not actively participate or become passive in the classroom despite encouragements and use of various teaching methods by the instructors to stimulate active participation

Copyright (C) 2017 The Authors. Published by Aleksandras Stulginskis University. This is an open-access article distributed under the terms of the Creative Commons Attribution License (CC-BY 4.0), which permits unrestricted use, distribution, and reproduction in any medium, provided the original author and source are credited. 
from the students. Consistently, we can hypothesize that students are passive or can become passive in the classroom due to self-limitations, such as fear of offense (Siti Maziha, Nick Suryani \& Melor, 2010, low levels of self-confidence, fear of showing their intelligence, fear that their answers will be critisezed by the instructors and peer students and the feelings of confusion (Fassinger, 1995; Gomez, Arai \& Lowe, 1995)

Research aim: to compare the results obtained on student passivity in 2005 and 2017 and the class-work methods helpful in breaking silence and passivity as well as improving students' motivation for learning English as a foreign language.

\section{Research objectives:}

1. To analyse the factors contributing to the student passivity in the classroom;

2. To discuss the class-work methods helping to break the students' silence and passivity;

3. To reveal the influence of psychological climate on students' passivity.

Research object: students' passivity in the English classroom at the University of Agriculture (present Aleksandras Stulginskis University) in 2005 and at Aleksandras Stulginskis University in 2017.

\section{DATA COLLECTION}

The research was carried out by way of questioning 66 students at Aleksandras Stulginskis University (former University of Agriculture) in the spring of 2005 and 66 students in the spring of 2017 and observation. In both years they represented 4 groups of the first and second year students from 2 faculties: the Faculty of Economics and Management and the Faculty of Forestry and Ecology. The results of the preliminary written test were chosen as a starting point of the assessment of the students' background knowledge. The assessment results of the written preliminary test, and the results of the written and oral examinations of the first and second terms in 2005 and due to the changes in study programmes which took place in 2013/2014 school year (since then the first year students have started their English classes in the second term) the assessment results of the preliminary written test, written and oral examinations of the second and third terms in 2017 were used to evaluate the students' progress. The data compiled in Table 1 revealed that there was no significant difference between the background knowledge (preliminary written test) of the first year students from the Faculty of Forestry and Ecology as well as of the first and second year students from the faculty of Economics and Management.

Table 1. Assessment results of the $1^{\text {st }}$ and $2^{\text {nd }}$ year students (the Faculty of Forestry and Ecology and the Faculty of Economics and Management) in 2005

\begin{tabular}{|c|c|c|c|c|c|c|}
\hline \multirow[t]{3}{*}{ Faculty } & \multirow[t]{3}{*}{ Year } & \multirow{3}{*}{$\begin{array}{l}\text { Diagnostic } \\
\text { test }\end{array}$} & \multicolumn{4}{|c|}{ Term and examinations } \\
\hline & & & \multicolumn{2}{|c|}{$1 \mathrm{st}$} & \multicolumn{2}{|c|}{ 2nd } \\
\hline & & & written & oral & written & oral \\
\hline Forestry & I & 3.36 & 3.60 & 6.10 & 5.25 & 7.00 \\
\hline Forestry & II & - & 6.43 & 7.25 & 7.03 & 7.73 \\
\hline Economics & $\mathrm{I}$ & 5.56 & 7.06 & 8.00 & 7.55 & 8.30 \\
\hline Economics & II & - & 7.25 & 7.71 & 7.90 & 8.27 \\
\hline
\end{tabular}

Data in table 1 reveal a marked difference in the students' diagnostic test achievements between the faculties. It amounts to 2 points. The results for the subsequent two terms showed considerably better results of both written and oral examinations in both faculties. Both active and passive students from the Faculty of Economics and Management positively evaluated their language achievement (Table 1). 50\% of the first year students stated that progress was satisfactory and $37 \%$ that it was good, while $50 \%$ of the passive students pointed out that it was satisfactory and $43 \%$ indicated that it was slightly satisfactory. The results of the second year students were rather optimistic. $60 \%$ of the active students and $43 \%$ of the passive learners indicated that they were satisfied with the results achieved. $30 \%$ of the active students and $57 \%$ of the passive respondents pointed out that they might have achieved better progress in English.

Different results were obtained in the Faculty of Forestry. $43 \%$ of the first year and $33 \%$ of the second year motivated students indicated that they had made progress in speaking English (Table 1).

Table 2. Assessment results of the $1^{\text {st }}$ and $2^{\text {nd }}$ year students (the Faculty of Forestry and Ecology and the Faculty of Economics and Management) in 2017

\begin{tabular}{|c|c|c|c|c|c|c|c|c|}
\hline \multirow[t]{3}{*}{ Faculty } & \multirow[t]{3}{*}{ Year } & \multirow{3}{*}{$\begin{array}{l}\text { Diagnostic } \\
\text { test }\end{array}$} & \multicolumn{6}{|c|}{ Term and examinations } \\
\hline & & & \multicolumn{2}{|c|}{$1 \mathrm{st}$} & \multicolumn{2}{|c|}{ 2nd } & \multicolumn{2}{|c|}{$3 \mathrm{rd}$} \\
\hline & & & written & oral & written & oral & written & oral \\
\hline Forestry & I & 6.63 & - & - & 5.75 & 7.57 & - & - \\
\hline Forestry & II & 6.25 & - & - & 5.39 & 7.18 & 6.80 & 8.46 \\
\hline Economics & $\mathrm{I}$ & 6.24 & - & - & 5.43 & 7.16 & - & - \\
\hline Economics & II & 5.90 & - & - & 5.55 & 7.25 & 6.48 & 7.81 \\
\hline
\end{tabular}

Data in table 2 show that there was no significant difference in the diagnostic test results between the considered faculties. $68 \%$ of the students from the Faculty of forestry and Ecology and 55\% of the students from the Faculty of Economics and Management indicated that they were disappointed with worse achievements in the written examination, thus it allows to conclude that one term interval between the diagnostic test and the beginning of the classes had a negative 
effect on student achievement from both faculties. The results of the second year students were rather promising. $78 \%$ of the active students and $60 \%$ of the passive learners indicated that they were satisfied with the achieved results

The questionnaire was developed to clarify the reasons of silence and passivity in the English classes and reveal the role of class-work methods aiming at eliminating these negative aspects.

For this reason the target students were asked to fill in an anonymous questionnaire that contained the following questions:

1. Has your knowledge improved over the years of study at the University?

2. What influence will the English language have on your future?

3. What is the atmosphere in the English classroom?

4. Are you active in your English class?

5. Are you passive in your English class?

6. What classroom activities are the most stimulating?

The students participating in the survey assessed their foreign language achievements, active methods applied in the classroom as well as the prevailing atmosphere during the English classes. They also speculated on what influence the English language and skills acquired in the English classes might have on their future.

In 2005 data were analyzed with the help of EXCEL, significance of changes in data on achievements by STATISTICA6.0 software. In 2017 data were analyzed with the help of EXCEL, significance of changes in data on achievements by STATISTICA-9.0 software. The obtained results were cross analyzed between the years

\section{FINDINGS AND THE RESULT ANALYSIS}

\section{Comparative analysis of the students' passivity and factors contributing to it}

The comparative analysis revealed slight but positive changes in teaching learning process. The results obtained in 2005 showed that $56 \%$ of the 33 first year students from the Faculty of Economics and Management considered themselves to be passive in the English classes. Data in Fig. 1 presents results on the factors contributing to their passivity: the unwillingness to show emotions $-33 \%$, the habit to be silent $-28 \%$, lack of knowledge $-20 \%$, laziness $-9 \%$, and fear of the teacher $6 \%$. The students indicated that they were shy and afraid of showing emotions since the first English class at the university. In 2017 the number of the first year passive students of the above mentioned faculty decreased and made $34 \%$. The reasons for that remained the same: the unwillingness to show emotions $-20 \%$, the habit to be silent $-25 \%$, lack of knowledge $-8 \%$, laziness $-25 \%$, and fear of the teacher $7 \%$. The comparative analysis of the presented data showed some significant differences between the years 2005 and 2017: unwillingness to show emotions decreased from $33 \%$ to $20 \%$, the habit to be silent decreased from $28 \%$ to $25 \%$, lack of knowledge decreased from $20 \%$ to $8 \%$, laziness increased from $9 \%$ to $25 \%$, fear of the teacher remained at the fairly the same level 6 and $7 \%$, respectively.

The number of the 33 passive second year students in 2005 amounted to $46 \%$. The main contributing factors remained the same as they used to be in the first year: unwillingness to show emotions $-27 \%$, habit to be silent $-20 \%$, lack of knowledge $-15 \%$, laziness $18 \%$ and fear of the teacher 5\%. In 2017 the number of the passive students dropped to $30 \%$. Unwillingness to show emotions made $35 \%$, habit to be silent $-14 \%$, lack of knowledge -15 , laziness $20 \%$ and fear of the teacher $6 \%$.

The comparative analysis of the results obtained in 2005 and 2017 revealed that unwillingness to show emotions increased from $27 \%$ to $35 \%$, habit to be silent decreased from $20 \%$ to $14 \%$, lack of knowledge remained at the same $15 \%$ level, laziness increased from $18 \%$ to $20 \%$, and fear of the teacher remained at fairly the same level with an increase of $1 \%$.

The results obtained in the Faculty of Forestry and Ecology in 2005 showed that $78 \%$ of the 33 first year students from this Faculty were passive in their English classes. The reason for that were as follows the habit to be silent - $28 \%$ and laziness - 25\%), unwillingness to show emotions - 18\% and lack of knowledge - $17 \%$ and fear of the teacher made $5 \%$. The analysis of the data showed that the students from the Faculty of Forestry and Ecology were shy and afraid of showing emotions since their first day at the university. The results for 2017 were rather different and optimistic. The number of the 33 first year passive students decreased to 55\%. The reasons for that were as follows: the habit to be silent $21 \%$, laziness (33\%); unwillingness to show emotions $-23 \%$, lack of knowledge (12\%), and fear of the teacher (3\%).

The comparative analysis revealed that unwillingness to show emotions increased from $18 \%$ to $23 \%$, habit to be silent decreased from $28 \%$ to $21 \%$, lack of knowledge remained at almost the same level and decreased by $5 \%$ i.e. from $17 \%$ to $12 \%$, laziness increased from $25 \%$ to $33 \%$, and fear of the teacher remained at fairly the same level with a decrease of $1 \%$.

The number of the 33 second year passive students in 2005 though slightly but decreased by approximately $10 \%$ (from $78 \%$ to $68 \%$ ) but it was higher than the number of the active students. As the main reasons for their passivity were pointed out the following factors: the habit to be silent $25 \%$, laziness $-25 \%$, unwillingness to show emotions $-18 \%$, lack of knowledge $-20 \%$, fear of the teacher $-4 \%$. These factors had a crucial influence on the students' academic achievements. the deeply rooted habit to be silent as one of the reasons for their passivity. In 2017 the number of the passive second year students dropped to 35\%. As the main reasons for their passivity were pointed out the following factors: the habit to be silent $26 \%$, laziness $-24 \%$, unwillingness to show emotions $-26 \%$, lack of knowledge - $19 \%$, fear of the teacher $-1 \%$.

The comparative analysis of the results obtained in 2005 and 2017 revealed that unwillingness to show emotions increased from $18 \%$ to $26 \%$, habit to be silent increased from $25 \%$ to $26 \%$, lack of knowledge and laziness remained at the same level with decrease of $1 \%$, and fear of the teacher dropped from $4 \%$ to $1 \%$. The students observed that they coped with the habit to be silent, they were not so lazy and their knowledge has improved. 

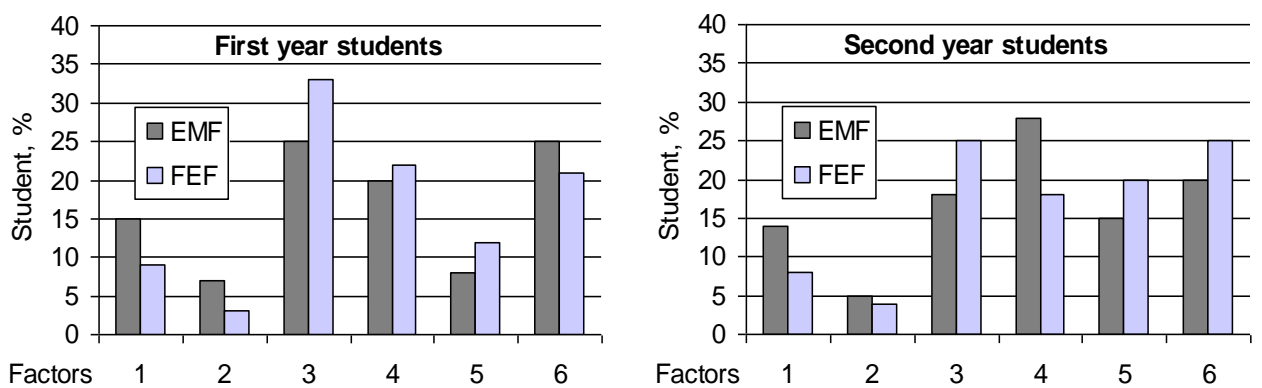

1 - boring classes; 2 - fear of the teacher; 3 - laziness; 4 - unwillingness to show emotions; 5 - lack of knowledge; 6 - habit to be silent

Figure 1. Causative factors contributing to the first year students' passivity in the faculties of Economics and Management and Forestry and Ecology in 2005
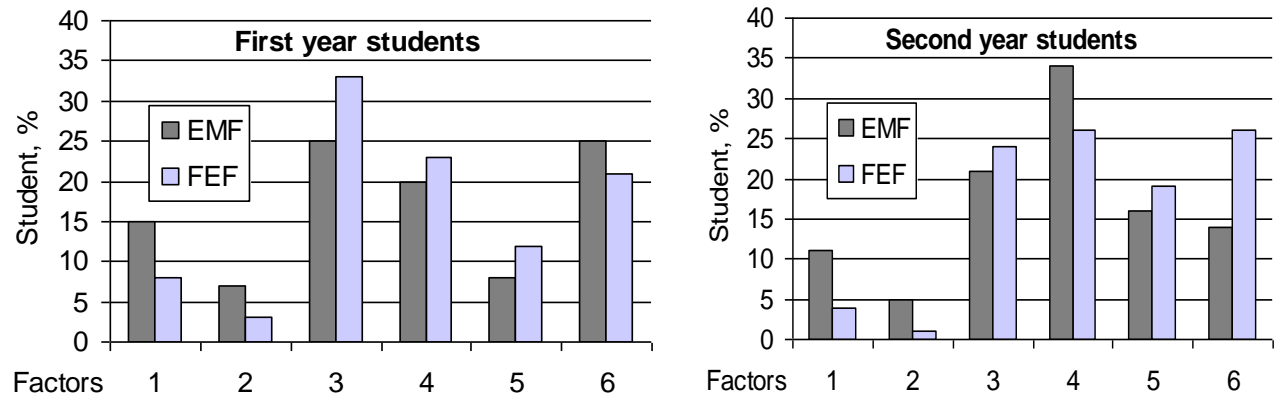

1 - boring classes; 2 - fear of the teacher; 3 - laziness; 4 - unwillingness to show emotions; 5 - lack of knowledge; 6 - habit to be silent

Figure 2. Causative factors contributing to the first year students' passivity in the faculties of Economics and Management and Forestry and Ecology in 2005

Generalisation of the causative factors contributing to students' passivity (Fig.1 and 2) both in 2005 and 2017 indicated that it was highly influenced by the deeply rooted habit to be silent and lack of knowledge. Among the remainder causative factors prevailed laziness and unwillingness to show emotions. In the Faculty of Forestry (male dominance) laziness was ticked by the majority of the respondents, while in the Faculty of Economics and Management (female dominance) unwillingness to show emotions was indicated as the most important cause for being passive. The selected answers revealed no significant differences in the learners' attitude to the factors influencing students' activity in both faculties. Communicative activities had the most positive effect on students' activity while the least - wish to be intelligent and progress in 78 academic achievement.

\section{Influence of class-work methods on learners' activity}

Both in 2005 and 2017 an attempt was made to identify the most beneficial methods for stimulating students' activity. The obtained data proved the efficiency of the below presented methods widely applied in the classroom for reducing learners' passivity. They were as follows: discussion, team work, pair work, and presentation making. The analysis of the data revealed a difference in active and passive learners' approach to the evaluation of the methods being used. Data presented in Fig.3 revealed that discussions were most favored by active students both in 2005 and 2017 and made 39\% and 44\%, respectively, followed by presentation making $22 \%$ and $20 \%$, respectively and team work - $22 \%$ and $29 \%$, respectively. Pair work was marked as the least acceptable method of learning in both 2005 and 2017 and made $18 \%$ and 7\%, respectively. The results of the comparative analysis of the data obtained in 2005 and 2017 for passive learners showed that number of students who preferred team work to any other class-work method decreased from $48 \%$ to $32 \%$, but surprisingly the number of those who preferred discussion increased by a 50\% (from $18 \%$ to $36 \%$ ), data on team work showed a significant drop from $48 \%$ in 2005 to $32 \%$ in 2017 and data on pair work method showed a 5\% decrease from $23 \%$ to $18 \%$. The applied methods not only improved active learners' performance but also stimulated passive students' activity.
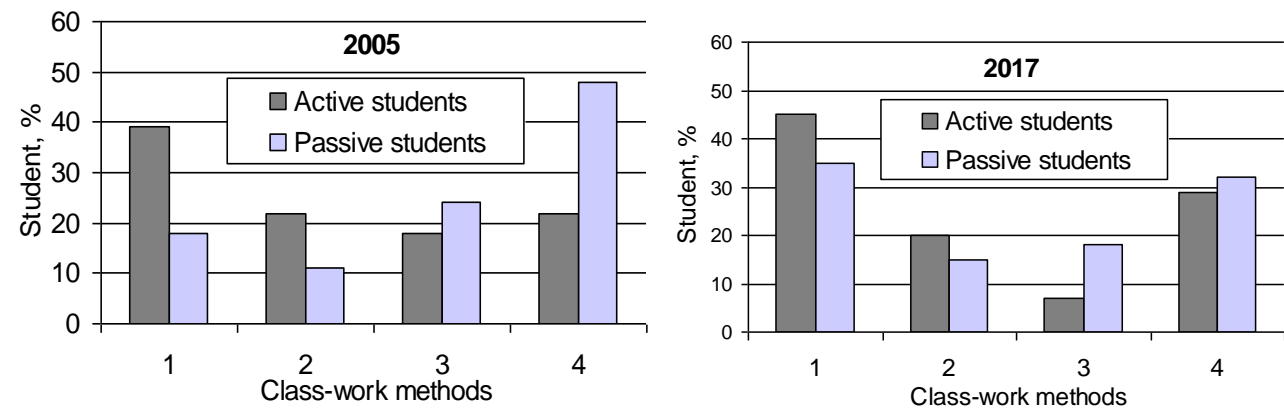

(Class-work methods: 1 - discussion, 2 - presentation making, 3 - pair work, 4 - team work).

Figure 3. Class-work methods contributing to students' activity 


\section{Learners' attitudes towards the atmosphere in the classroom}

The results for the 2005 indicated that active students from both faculties considered the atmosphere in the English classroom as relaxed 48\%, 32\% as quite relaxed, $17 \%$ as quite stressful, and only $3 \%$ as stressful, while the results obtained from the passive students showed that $32 \%$ perceived the atmosphere in the classroom as relaxed, $39 \%$ as quite relaxed, $19 \%$ as quite stressful, and 5\% as stressful. In 2017 of all the questioned students the active students considered the atmosphere in the classroom as: relaxed - $68 \%$, quite relaxed $-28 \%$, quite stressful $-4 \%$ and none of the students considered it as stressful. In 2017 the situation appeared to very similar to that of (Fig. 4). Class-work methods proved to be efficient when the atmosphere in the classroom was relaxed.
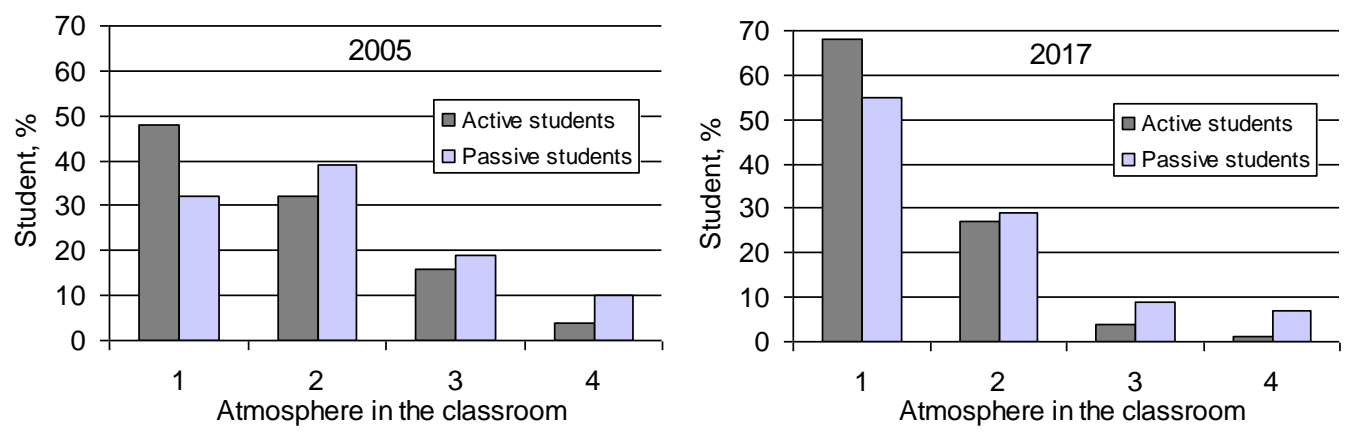

1 - Relaxed, 2 - quite relaxed, 3 - quite stressful, 4 - stressful

Figure 4. Active and passive students' attitudes towards the atmosphere in the classroom

Slight but positive results could have been observed between the considered years. The number of students who considered the atmosphere as relaxed increased by $20 \%$. None of the students assessed it as stressful at the end of the second year. The number of those who defined it as quite stressful dropped to 7\%, whereas the number of those who regarded it as relaxed increased up to $17 \%$. Thus, both active and passive students in both considered years appreciated relaxed and not stressful atmosphere in the classroom and $60 \%$ of passive students indicated that it helped them to be more active and consistently led to better academic achievements.

\section{DISCUSSION}

The majority of teachers faces students' attendance problems, their failure to meet the deadlines or total indifference to participate in classroom activities, that is they are simply passive and bored (Biggs, 2011). There are many factors that might influence students' commitment to study. Many things - perhaps most of them - are beyond language teachers' control such as family background, health problems, events of their personal life, character traits, etc. These factors might have some influence on their being active or passive in the classroom. Success in foreign language learning has been attributed to individual differences such as intelligence, aptitude, personality, motivation, and anxiety (Rossiter, 2010). However, in general, silence is related to fear of saying the wrong thing, showing emotions, being negatively judged not only by a teacher, but also by group-mates (King, 2013).

In the research the main reasons of students' passivity were identified. The obtained data indicated that the majority of the first year students from both faculties were passive. This percentage slightly decreased in the second year (by approximately 10\%). The key reasons for being passive in the Faculty of Economics and Management were mentioned unwillingness to show emotions due to the deeply rooted habit or lack of knowledge, while in the Faculty of Forestry and Ecology - fear to show emotions. The obtained results let us think that students' passivity comes from their previous learning experience where typical form of interaction that failed to initiate students' activities in a constructive and productive manner (King, 2013). We should admit that students especially in rural schools have limited chances to participate actively in the teaching/learning process. Therefore they feel tongue-tied, embarrassed while speaking. They definitely lack self-confidence in themselves as learners. We attempted to identify the reasons for these changes, especially of why the students are increasingly unwilling to show their emotions and where does it stem from. The findings showed that the main reasons for that were that they are simply in the habit of staying silent and are afraid that their knowledge might be insufficient for expressing their ideas 50\%, 20\% indicated that they are simply lazy, the rest indicated that they did not know. These findings led us to conclusion that the students lack motivation and the level of their engagement in the learning process is low.

The idea that a foreign language (English) could be learned by memorising lists of vocabulary and grammar rules and by continuous reference to one's native tongue has been rejected by the majority of foreign language teachers.

Recent developments in foreign language teaching indicate a trend towards the development of the communicative competence (Alcon, 2008; Mehisto, 2008; Richards, 2014).

In this setting encouraging communicative classroom participation is one of the greatest challenges for ESL teachers. Lots of communicative activities and class-work methods are designed to provoke spoken communication and stimulate students' involvement as well as deal with the problem of student participation (Pachler, 2009; Ohta, 2001). 
The results obtained from our survey indicated that for the active students the most acceptable class-work method was discussion followed by presentation and team work, while the passive students indicated that discussion and presentation making were the most stressful classroom activities. The reason might be lack of knowledge and skills as well as personality problems, such as embarrassment and fear to be judged negatively both by a teacher and group-mates. However, active class-work methods made them change. The majority of them indicated that they had improved their ability to communicate.

No doubts, learning a foreign language requires a supportive atmosphere. The students need the environment in which they do not feel threatened or intimidated and they need to be heard. Shrum and Glisan (2005) noted that competition in language learning might cause anxiety, inadequacy, hostility, fear of failure, guilt and too strong desire for approval'. The above mentioned class-work methods seem to be helpful in building self-esteem and increasing motivation.

\section{CONCLUSION}

Lack of knowledge and necessary skills to communicate are the key reasons for students' passivity. In addition, laziness in most cases for male students and unwillingness to show emotions for female students strengthen this effect. On the other hand active class-work-methods stimulate students' activity and help them overcome unwillingness and fright to communicate in English.

The results of the comparative analysis of the data obtained in 2005 and 2017 for passive students is rather optimistic. The decrease in the number of the students who preferred pair and team work to any other class-work method and a significant increase in the number of those who preferred discussion indicates that the students are increasingly becoming more self-confident and active. The relaxed atmosphere also has a positive effect on both student activity and academic achievements

\section{REFERENCES}

1. Augustaitiene, I., Barzdziukiene, R. 2007. Communicative Competence and Grammatical Accuracy. In Spiritual values in Knowledge Society. Lithuanian University of Agriculture.

2. Alcon, E, Safont, M.P. (eds.) 2008. Intercultural Language Use and Language Learning. Berlin: Springer.

3. Biggs, J.,Tang, C. 2011. Teaching for Quality Learning at University: What the student does. McGraw-Hill Education. Oxford University Press.

4. Fassinger, P. A. 1995. Professors'and Students' Perception of Why Students Participate in Class. Teaching sociology, Vol. 24, pp. 25-33. https://doi.org/10.2307/1318895

5. Forrest, A. 2004. The Challenge of Languages in Europe, Hendrik Brugmans Memorial Lecture. Available at: http://www.madariaga.coleurop.be/docs/speech99.pdf

6. Gomez, A. M. Arai, M.J., Lowe, H. 1995. When Does a Student Participate in Class? Ethnicity and Classroom Participation. Paper presented at the Annual Meeting of the Speech Communication Association (81 ${ }^{\text {st }}$, San Antonio, TX)

7. King, J. 2013. Silence in the Second Language Classroom. Oxford: Macmillan, pp.83-86. https://doi.org/10.1057/9781137301482_5

8. Mehisto, P., Marsh, D., Frigols, M. 2008. Uncovering CLIL: Content and Language Integrated Learning in Bilingual and Multilingual Education. Oxford: Macmillan.

9. Mohd Yusof, A., Abu Bakar, N.R. Mahbob, M.H. Student's Participation in Classroom: What Motivates Them to Speak up? Elsevier. Procedia - Social and Behavioral Sciences, Vol. 51, pp. 516-522. https://doi.org/10.1016/j.sbspro.2012.08.199

10. Ohta, A.S. 2001. Second Language Acquisition in the Classroom Mahwan, NJ: Lawrence Erlbaum Associates.

11. Pachler, N., Barners A., Field, K. 2009. Class-work Methods Teaching Languages. New York: RefineCatch Ltd., pp. 228-230

12. Richards, J.C., Rodgers, T.S. 2014. Approaches and Methods in Language Teaching. Cambridge University Press, pp.81-82

13. Rossiter, M.J. 2010. The Effects of Affective Strategy Training in the ESL Classroom. University of Alberta, Available at: http://www-writing.berkeley.edu/TESL-EJ/ej26/a2.html

14. Shrum, J.L., Glisan, E.W. 2005. Teacher's Handbook: Contextualized Language Instruction. Boston, MA: Heinle and Heinle Publishers.

15. Vez, J.M. 2009. Multilingual Education in Europe: Policy Developments. Available at: http://www.ugr.es/ portalin/articulos/PL_numero12/ 1JM\%20Vez.pdf 